University of Nebraska - Lincoln

DigitalCommons@University of Nebraska - Lincoln

Papers in the Earth and Atmospheric Sciences

Earth and Atmospheric Sciences, Department

June 1900

\title{
Report on the Work of the Morrill Geological Expeditions of the University of Nebraska
}

Carrie Adeline Barbour

University of Nebraska-Lincoln

Follow this and additional works at: https://digitalcommons.unl.edu/geosciencefacpub

Part of the Earth Sciences Commons

Barbour, Carrie Adeline, "Report on the Work of the Morrill Geological Expeditions of the University of Nebraska" (1900). Papers in the Earth and Atmospheric Sciences. 52.

https://digitalcommons.unl.edu/geosciencefacpub/52

This Article is brought to you for free and open access by the Earth and Atmospheric Sciences, Department of at DigitalCommons@University of Nebraska - Lincoln. It has been accepted for inclusion in Papers in the Earth and Atmospheric Sciences by an authorized administrator of DigitalCommons@University of Nebraska - Lincoln. 
REPORT ON THE WORK OF THE MORRILL GEOLOGICAL EXPEDITTONS OF THE UNIVERSITY OF NEBRASKA.*

Throvgh the generosity of the Hon. Charles H. Morrill, of Lincoln, the expeditions sent out from the University of $\mathrm{Ne}$ braska, known as the Morrill Geological Expeditions, have become a permanent organization of the University. Therefore, it is but a fitting mark of respect that reports of these expeditions be given to the Nebraska Academy of Science from time to time in order that they may become matters of record. Introductory to this work, a private geological excursion was undertaken in June of 1891, by Mr. Erwin Hinckley Barbour in the interest of the University of Nebraska. At this time the Dæmonelix beds of our State were discovered and explored, and the Bad Lands of Nebraska and regions in South Dakota were visited, the result being that a very considerable collection was made and several new genera and species found. In May of 1892 a second trip (likewise at private expense) was made to the Sioux county Bad Lands and to the Dæmonelix beds. Again a large amount of material was secured and added to the collections of the State Museum. At this

* Paper read before the Nebraska Academy of Science. 
juncture the Hon. Charles H. Morrill, of Lincoln, came forward with liberal contributions for the prosecution and continuance of the work. Then followed during June, July and August of the same year the first of what has become the annual Morrill Geological Expeditions.

A well equipped party of six (exclusive of guide) namely: T. H. Marsland, F. C. Kenyon, A. C. Morrill, H. H. Everett, J. H. Haines and Erwin H. Barbour in charge, visited the Bad Lands of the State, and especially the Dæmonelix beds, continuing thence into South Dakota and to the Dinosaur beds of Wyoming.

In 1893 a similar sum given by $\mathrm{Mr}$. Morrill made possible the second annual Morrill Geological Expedition which visited and collected in the Rhinoceros beds of Kansas, the Hat Creek Bad Lands and the fossil Corkscrew beds in the Loup Fork Tertiary of Sioux county. The party consisted of T. H. Marsland, H. H. Everett, with Erwin H. Barbour in charge. Later the director of the expedition extended the work of collecting to the Middle and New England States.

The third annual Morrill Geological Expedition, 1894, consisting of U. G. Cornell, H. H. Everett, A. C. Morrill, E. L. Morrill, J. P. Rowe, Samuel McCormick, guide, Erwin H: Barbour, as director, drove from Hot Springs to the Big Bad Lands of South Dakota where some six or eight weeks were spent, thence to the Black Hills and beyond into Wyoming and Montana. The result of the expedition being that an unusually large amount of material of great variety including fossils, minerals, rocks, etc., was secured.

In 1895 the fourth annual Morrill Geological Expedition consisting of U. G. Cornell, H. H. Everett, F. G. Hall, G. H. Hall, E. F. King, J. P. Rowe, G. R. Wieland, T. H. Marsland, Francis Roush, guide, Erwin H. Barbour in charge, con- tinued work from the Dæmonelix beds and the Little Bad Lands of Nebraska to the Big Bad Lands of South Dakota thence to the Black Hills and beyond. This was the largest and best equipped party sent out as yet.

In 1896 the fifth annual Morrill Geological Expedition extended its work to eastern fields, spending some time in the Carboniferous of Nebraska, a week in the Devonian of New York, and a couple of weeks in the Silurian of Ohio and Indiana.

In the summer of 1897 the sixth annual Morrill Geological Expedition consisting of B. G. Almy, U. G. Cornell, O. A. Reitz, Francis Roush, guide, Carrie A. Barbour, E. H. Barbour in charge, again visited and collected in the Big Bad Lands of South Dakota, the Black Hills region, the Little Bad Lands, the Dæmonelix bed of Nebraska and beyond into Wyoming.

In 1898 , the seventh expedition was influenced by the Trans-Mississippi Exposition in Omaha, and the museum force and assistants in the geological department became interested in the preparation of exhibits illustrating our natural resources. The quarries of the State, more particularly those of southeastern Nebraska, were visited and important economic sets of building stones, clays, soils, etc., were added to the Morrill collections.

The eighth expedition, 1899, was divided into five distinct parties, two of which were provided with teams and camp accoutrements, the other parties going by rail from place to place. A party of two followed the Dakota cretaceous from Oklahoma to South Dakota. Another drove through the quarry regions in southeastern Nebraska. A third party, a graduate student in the department of geology, spent the summer collecting Bryozoa in the Carboniferous.

The writer with assistants, spent some weeks collecting invertebrate fossils in the carboniferous exposures, while the director, 
with an assistant, visited fields in Wyoming, Montana, Dakota, and Nebraska. Over two hundred boxes of excellent material were added to the collections of the State Museum.

A geological expedition for 1900 is already assured by a recent gift, to that end, made by Mr. Morrill to the Board of Regents of the University of Nebraska.

In each instance the Burlington \& Missouri River Railroad furnished free transportation for the party and 'outfit' as well as for all material collected. So with free transportation, and the gratuitous service of students of the University of Nebraska and with all expenses defrayed by the Hon. Charles H. Morrill, a maximum amount of material at a minimum cost was massed together. Sets of duplicate specimens have since been donated to 40 accredited high schools, academies, and colleges in the State, and exchanges have been made with the following universities: Ohio, Utah, Kansas, Minnesota, Columbia, Case School of Applied Science and to the Field Columbian Museum, and the National Museum. These collections seem to have unusual exchange value, the demand for them even exceeding the supply. The usefulness then of Mr. Morrill's work has extended beyond the limits of the State, and while contributing to the cabinets of others, his own collections have been so enriched as to fill most of the cases on the main floor of the State Museum and some of the cases on the second floor.

Carrie Adeline Barbour.

The UnIversity of Nebraska. 